\title{
Turnover of dimethylsulfoniopropionate and dimethylsulfide in the marine environment: a mesocosm experiment
}

\author{
Rik L. J. Kwint ${ }^{1,2}{ }^{, *}$, Peter Quist ${ }^{1}$, Theo A. Hansen ${ }^{1}$, Lubbert Dijkhuizen ${ }^{1}$, Kees J. M. Kramer ${ }^{2, * *}$ \\ ${ }^{1}$ University of Groningen, Department of Microbiology, PO Box 14,9750 AA Haren, The Netherlands \\ ${ }^{2}$ TNO Institute of Environmental and Energy Research and Process Innovation, Department for Ecological Risk Studies, \\ PO Box 57, 1780 AB Den Helder, The Netherlands
}

\begin{abstract}
ARSTRACT: The production of dimethylsulfoniopropionate (DMSP) by marine phytoplankton and the fate of the produced DMSP and dimethylsulfide (DMS) were studied in 4 pelagic mesocosms during an algal bloom over a period of 1 mo. Bacterial numbers, concentrations of particulate and dissolved DMSP, DMS, and chlorophyll a were monitored, as well as the turnover rates of DMS and DMSP. Of the total amount of DMSP produced, only a fraction could be detected as DMS in the water colunn. DMS production in the water column did not necessarily correlate with algal senescence, but also occurred during the maximum of the algal bloom. The flux of DMS to the atmosphere played a minor role as a sink for DMS. Evidence is presented that shows bacterial consumption to be a major sink for DMS, under conditions of both high and low DMS water concentrations. DMSP was degraded either via cleavage or via demethylation; the results indicate a predominant role for the latter route.
\end{abstract}

KEY WORDS: Dimethylsulfoniopropionate Dimethylsulfide Bacteria Phytoplankton Flux

\section{INTRODUCTION}

On the basis of its concentration and turnover, dimethylsulphide (DMS) is one of the most important biogenic sulphur compounds in the marine environment. It accounts for over $50 \%$ of the total biogenic sulphur $\left(10^{11} \mathrm{~kg} \mathrm{~S}\right)$ entering the atmosphere annually, and about $90 \%$ of the DMS originates from marine sources (Andreae 1990). In the marine environment, DMS is mainly formed by the cleavage of $\beta$-dimethylsulphoniopropionate (DMSP), an osmoregulator in marine algae (Vairavamurthy et al. 1985, Dickson \& Kirst 1987a, b).

The efflux of DMS to the atmosphere and the factors controlling this deserve special attention because of their (3-fold) effects. Firstly, since the work of Lovelock et al. (1972), it has been accepted that DMS is the main vehicle by which the global sulphur cycle is balanced.

\footnotetext{
·E-mail lamr@tno kribc.nl

- Present address: Mermayde, PO Box 109, 1860 AC Bergen,

The Netherlands
}

Secondly, photochemical oxidation of atmospheric DMS into methanesulphonic acid and sulphate leads to acid precipitation. Thirdly, the efflux of DMS to the atmosphere results in an increase in the so-called 'cloud-condensation-nuclei', or CCN, which have a backscattering effect on solar radiation and influence cloud formation. A regulatory effect of CCN on global warming has been postulated by several authors (Bates et al. 1987, Charlson et al. 1987, 1991, Ayers \& Gras 1991).

Factors controlling the concentration of DMS in the water column (the parameter driving the release to the atmosphere) are not yet clearly understood, but include zooplankton grazing, algal senescence, algal and bacterial DMSP-lyase activity, and chemical breakdown of DMS (Dacey \& Wakeham 1986, Nguyen et al. 1988, Belviso et al. 1990, Belviso et al. 1993, Stefels \& Van Boekel 1993, De Souza \& Yoch 1995, Stefels et al. 1995).

The most important loss factors for DMS from surface waters are bacterial oxidation, (photojoxidation, and efflux to the atmosphere (Brimblecombe \& Shooter 
1986, Kiene 1992). Bacterial DMSP demethylation may also occur, providing an alternative route for DMSP metabolism that circumvents the formation of DMS (Fig. 1; Taylor \& Gilchrist 1991). Products thus formed include methylmercaptopropionate (MMPA), and mercaptopropionate (MPA). Stefels \& Van Boekel (1993) showed that bacteria-free cultures of the algae Phaeocystis sp. are able to convert extracellular DMSP into DMS using a DMSP-lyase enzyme; the algal contribution under field conditions is still unknown, however.

The particulate DMSP concentration in seawater shows seasonal fluctuations which correlate well with algal densities of certain species (Nguyen et al. 1988, Keller et al. 1989, Leck et al. 1990, Matrai \& Keller 1994). During algal blooms, high concentrations of DNISP and DMS are reached (Leck et al. 1990, Malin et al. 1993), especially when algae such as Phaeocystis sp. or Emiliania huxleyi are the dominant species (Matrai \& Keller 1993, Liss et al. 1994). For this reason, algal blooms may have pronounced effects on the annual global sea-air exchange of DMS. It is therefore of great importance to know what mechanisms control the DMS concentration in the watercolumn (DMS water concentration) under various conditions.

Kwint \& Kramer (1995) could not balance the production and consumption of DMS in an earlier mesocosm study in Den Helder, The Netherlands, unless bacterial degradation was used as 'a missing sink'. In the present study, quasi-field experiments were performed in mesocosms in which an algal bloom was induced to study the fate of DMSP and the relative importance of bacterial degradation and other sinks for DMS. Mesocosm experiments have the advantages that the same water mass and planktonic community can be followed over a relatively long period under quasi-field conditions, and that the system is easily accessible for sampling. Previous studies have shown

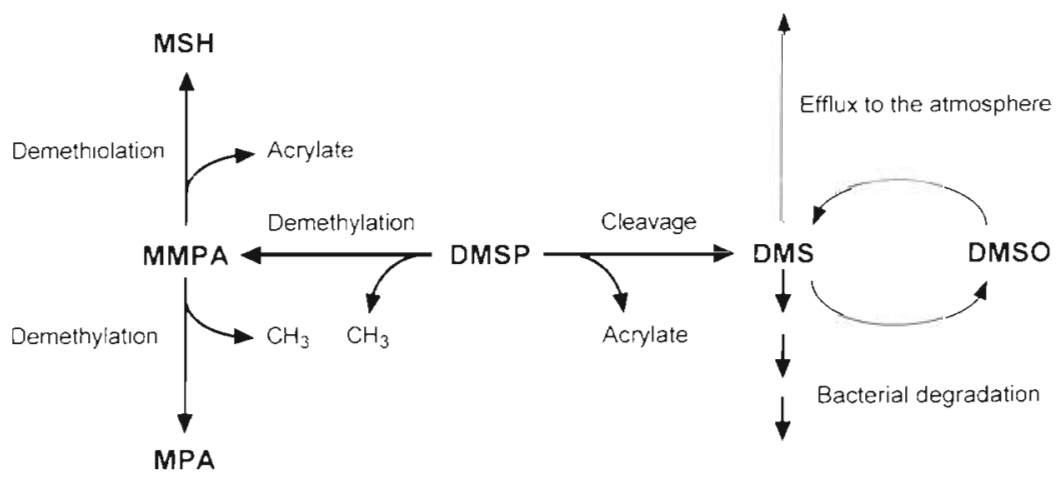

Fig. 1 Bacteral conversions of dimethylsulfoniopropionate (DMSP). Cleavage of DMSP yields dimethylsulfide (DMS) and acrylate. An alternative route for the degradation of DMSP is the demethylation via methylmercaptopropionate (MMPA) to mercaptopropionate (MPA). Demethiolation of MMPA results in methanethol (MSH) and acrylate that in such pelagic mesocosms replicable phytoplankton successions occurred and that the results could be extrapolated to the field situation (Kuiper 1977, 1981). Because of the high DMSP content of Phaeocystis sp., a bloom in which this species dominated was monitored.

\section{MATERIALS AND METHODS}

Mesocosms. The quasi-field experiments were carried out in 4 similar, free-floating, pelagial mesocosms as used by Kwint \& Kramer (1995). The same experimental setup was used for all 4 systems except for the presence of sediment traps in mesocosms 1 and 2 . The sediment traps (perspex cylinders (diameter $7.4 \mathrm{~cm}$, height $20 \mathrm{~cm}$ ) were mounted in a rigid PVC frame, at water depths of 0.5 and $2 \mathrm{~m}$ and were emptied daily. Results obtained from the sediment traps in the experiments are described in detail by Osinga et al. (1996). Two days before commencement, the mesocosms were installed in the Den Helder harbour, The Netherlands. The mesocosms consisted of large plastic bags (polythene/polyamide 2 -layered foil), each with a diameter of $72 \mathrm{~cm}$ and an approximate depth of $3.2 \mathrm{~m}$, thus having a volume of about $1300 \mathrm{l}$. The mesocosms were simultaneously filled with water from the Marsdiep (The Netherlands) tidal inlet on April 14, 1993, according to Kwint \& Kramer (1995). On Day 0, $40 \mu \mathrm{M}$ nitrate and $6 \mu \mathrm{M}$ phosphate were added to restore the levels of these nutrients to the winter levels in the nearby Marsdiep, thereby ensuring high planktonic growth. For $35 \mathrm{~d}$ almost daily representative samples were taken for the analysis of chlorophyll a (chl a), DMSP DMS, and nutrient concentrations.

Analysis. Water samples were collected in a depthtransect through the bags using a 3 l glass bottle and a peristaltic pump with teflon tubing The oxygen concentration, $\mathrm{pH}$, Secchi depth, particle data (Coulter Counter) and water temperature were measured daily. Subsamples for the determination of chl $a$, nutrient concentrations DMS, phytoplankton, bacteria densities and DMSP and for the short-time incubation experiments were immediately taken from this large sample. The remainder was returned to the mesocosm.

ChI a: Subsamples were stored in 11 polyethylene bottles in the dark until analysis within $2 \mathrm{~h}$ of sampling Samples were filtered on glass fibre filters (Whatmann GF/C), extracted with $90 \%$ acetone and analyzed by spectropho- 
tometry according to standard procedures (Parsons et al. 1984).

Nutrient concentrations: Subsamples were stored deep-frozen $\left(-25^{\circ} \mathrm{C}\right)$ until analysis for or thophosphate, ammonia, nitrate, nitrite and reactive silicate, using a 'Technicon' auto-analyzer (Parsons et al. 1984).

DMS: Subsamples were taken in amber $100 \mathrm{ml}$ glass-stoppered bottles and stored on ice. To check for losses during storage, occasionally duplicate samples were taken for DMS and DMSP and analyzed with an interval of about $1 \mathrm{~h}$. No obvious losses of particulate DMSP (DMSP $)$, dissolved DMSP (DMSP $)$ or DMS were detected. The samples were processed immediately after returning to the laboratory, usually within $4 \mathrm{~h}$ of sampling.

A gas-stripping cryotrapping method was used to concentrate the DMS samples (Kwint \& Kramer 1995). DMS was analyzed according to Lindqvist (1989) on a Varian 3700 gas chromatograph equipped with a capillary linear plot column and a photoionization detector using hydrogen as the carrier gas. Calibration was performed using DMS permeation tubes in a dynamic dilution system. Quantitative analysis of DMSP was possible after its alkaline conversion to acrylate and DMS (Dacey \& Blough 1987). Gravity filtration (Whatmann GF/C filters) was used to separate DMSP from $_{\mathrm{p}}$ DMSP $_{\mathrm{d}}$ (Stefels \& Van Boekel 1993).

Phytoplankton: Samples preserved with Lugols Iodine were counted and identified by inverted microscopy. At least 20 fields were counted per sample (magnification $400 \times$ )

Zooplankton: Samples were taken twice weekly with a $3 \mathrm{~m}$ long PVC pipe, equipped with a ball valve at the end, according to Kuiper (1981). In total, 35 l per sample were filtered over a $55 \mu \mathrm{m}$ mesh-sized nylon filter and immediately fixed with neutral buffered formalin. The filtered water was returned to the mesocosm. Zooplankton were counted and identified microscopically in a $1 \mathrm{ml}$ chamber Copepods were subdivided into adult copepods, copepodites and nauplii.

Bacteria: Samples for the estimation of total bacterial numbers and DMS consuming bacteria were taken 3 times per week from 2 mesocosms (1 and 3). Total bacterial cells were counted by epifluorescence microscopy (Hobbie et al. 1977). The filter-fixed cells were incubated for $10 \mathrm{~min}$ in the dark using bisbenzimide $(10 \mu \mathrm{M})(\mathrm{T}$ A. Hansen pers. comm.) instead of acridine orange. For the quantification of the DMS oxidizing population a most probable number (MPN) method was used (De Man 1975). Bacteria were incubated on a mineral medium with DMS as the only carbon source. The medium used for the triplicate 10 -fold dilution series $\left(10^{-3}\right.$ to $\left.10^{-9}\right)$ consisted of $5 \mu \mathrm{m}$-filtered autoclaved seawater supplemented with $37.4 \mathrm{mM}$ $\mathrm{NH}_{4} \mathrm{Cl}, 16.5 \mathrm{mM}$ 2-bis[2-hydroxyethyl]amino-2-[hy- droxymethyl]-1,3-propanediol, $1 \mathrm{mM} \mathrm{KH}_{2} \mathrm{PO}_{4}$ and $0.2 \mathrm{mM} \mathrm{FeNH}_{4}$-citrate (Janvier et al. 1985). The dilution series was incubated in an atmosphere of DMS in the dark at $25^{\circ} \mathrm{C}$ for $4 \mathrm{wk}$. The added amount of DMS resulted in a concentration of DMS in the medium $\left(\mathrm{DMS}_{\text {medium }}\right)$ of $200 \mu \mathrm{M}$. The atmosphere was refreshed weekly to assure the availability of sufficient oxygen and DMS. Positive tubes were scored on the basis of both acidification and increased turbidity. Positive tubes were double checked by transferring $5 \mathrm{ml}$ from the tubes to $15 \mathrm{ml}$ crimp seal vials closed with teflon-lined septa. After overnight incubation, DMS consumption was determined by headspace analysis. The computer program of Klee (1993) was used for data analysis.

Isolation of DMSP-utilizing bacteria: To determine the bacterial population diversity, subsamples from the mesocosms were directly spread on solid agarose plates $115 \mathrm{~g}$ agarose MP $\mathrm{I}^{-1}$ (Boehringer Mannheim, Germany), washed 3 times with a 100-fold volume of demineralised water] consisting of the MPN medium (Janvier et al. 1985) supplemented with $10 \mathrm{mM}$ DMSP as substrate. After 3 wk distinct colonies were transferred to fresh plates and control media without substrate to check for DMSP utilization. Subsamples inoculated in mineral medium supplemented with $10 \mathrm{mM}$ DMSP were used to screen the isolates for DMSP utilization and DMS, MMPA, or MPA production (Fig. 1).

DMSP and DMS conversion rate estimation: Samples for the duplicate estimation of bacterial DMSP and DMS conversion rates were taken twice weekly from mesocosm 1. Incubation took place in the dark at the in situ temperature. The samples ( $50 \mathrm{ml}$ volume) were incubated in amber $250 \mathrm{ml}$ screw-cap bottles with and without the addition of $500 \mu \mathrm{M}$ chloroform. At $t=0$ and after 2, 4 and $6 \mathrm{~h}$, duplicate bottles were used to determine the DMSP, DMSP $_{d}$ and DMS water $_{\text {concentrations, }}$ meaning that for each time $t, 2$ new bottles with and 2 new bottles without chloroform were used. The production and consumption rates for these compounds were calculated from the initial linear parts of the curves describing their changes in time. The results of an incubation were only used when the linear part of the curve covered at least 3 (duplicate) points. Consumption of DMS was blocked with $500 \mu \mathrm{M}$ of chloroform (Kiene \& Bates 1990), allowing an estimation of the net production rate of DMS. In control experiments the chloroform added had no effect on the DMSP-lyase activity of an axenic Phaeocystis sp. culture, while it completely blocked DMS oxidation by a DMS-utilizing bacterial culture (Matrai et al. 1995, J. Stefels pers. comm.). The concentration of DMSP $P_{d}$ did not increase in the presence of chloroform, which is in contrast with the findings of Wolfe \& Kiene (1993), but this is probably due to the high biomass of Phaeocystis sp. In this experiment the assumption was made that no 
DMSP $_{\mathrm{p}}$ was produced by phytoplankton during the $6 \mathrm{~h}$ incubation in the dark.

Flux: The DMS flux to the atmosphere was calculated on the basis of the model of Liss \& Merlivat (1986), taking actual water temperature and windspeed, obtained from a nearby meteorological station (within $1 \mathrm{~km}$ distance), into account. The concentration of DMS in the air (DMS $\mathrm{Dar}_{\mathrm{r}}$ ) was insignificant compared to the concentration in the water column (A. Baart pers. comm.) and therefore could be ignored in the calculation.

Reagents and chemicals. DMS and acrylate were obtained from Merck (PA quality). The $\mathrm{HCl}$ salt of DMSP was synthesized according to Chambers et al. (1987). Its identity and purity were checked by melting point determination, proton NMR, and after alkaline conversion to DMS, by comparison to a DMS standard. The bisbenzimide used was Hoechst dye 3258 .
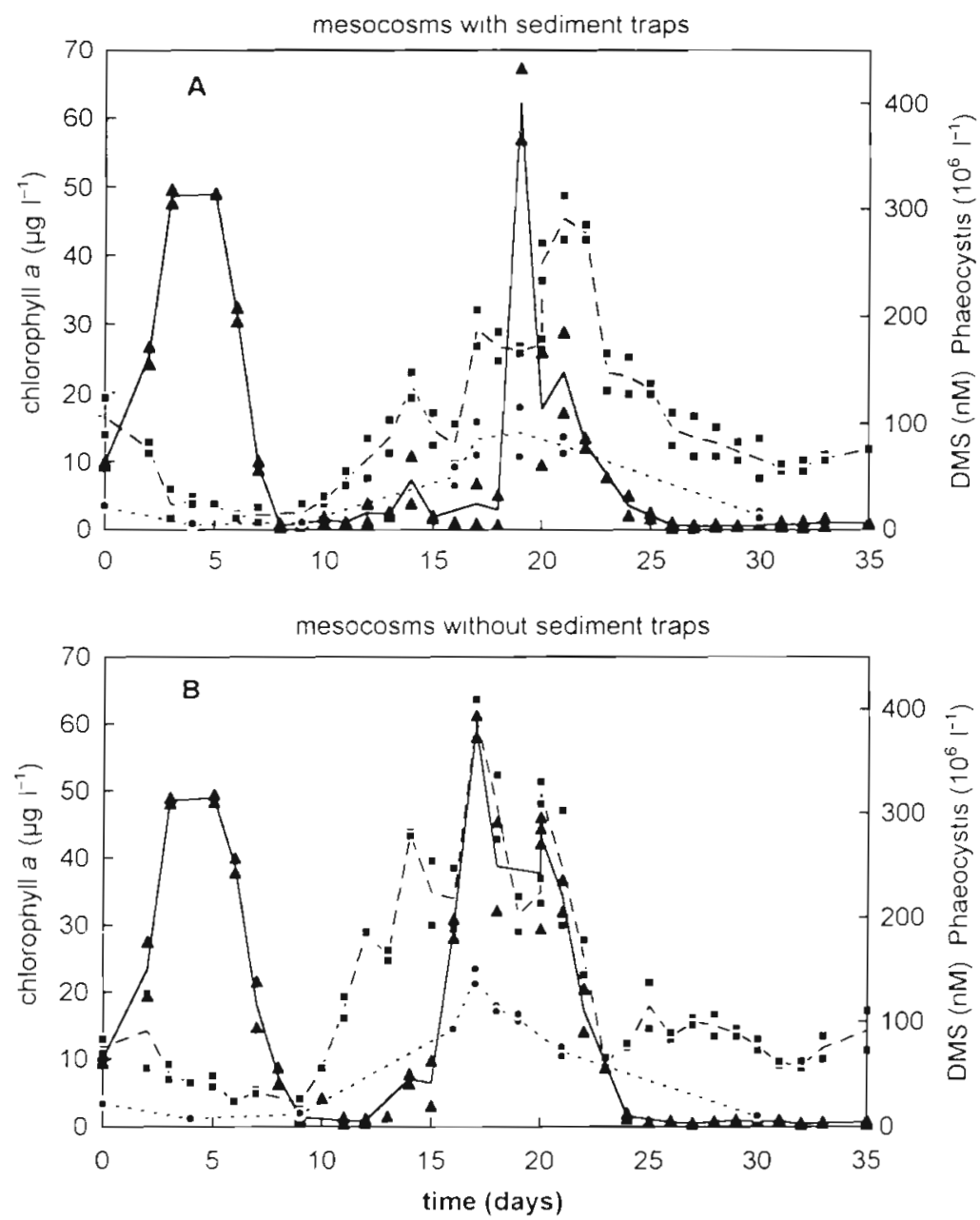

Fig. 2. Development of the DMS water concentration (4,-), chl a concentration $\left(\boldsymbol{\bullet}_{,},--\right)$and Phaeocystis cell density $(\bullet, \ldots)$ during the algal bloom: (A) mesocosms 1 and 2 with sediment traps; (B) mesocosms 3 and 4. without sediment traps. Points show measurements and lines show averages between duplicate mesocosms

\section{RESULTS AND DISCUSSION}

Plankton development

After sampling started at Day 0 , it took $5 \mathrm{~d}$ for the algae already present in the water column of the mesocosms to settle. These algae appeared unable to stay buoyant in the less turbulent environment of the mesocosms and as a result sedimentation took place. Fig 2 shows the chl a and the DMS water concentrations together with Phaeocystis sp. cell density with time. The settling of algae during the initial days gave rise to elevated levels of DMSP $_{d}$ and DMS concentrations (Figs. $2 \& 3$ ).

A bloom dominated by Phaeocystis sp., a DMSP producing species, started to develop from Day 10 onwards. After a peak at around Day 18 (up to $150 \times$ $10^{6}$ cells $l^{-1}$ ) the bloom collapsed at around Day 22. This was indicated by a decrease in the chl a concentration. The collapse was accompanied by nitrogen depletion; a decrease from 100 to about $1 \mu \mathrm{M} \mathrm{NO}_{3}$ was observed, suggesting that nutrient limitation rather than zooplankton grazing had caused the collapse. Diatoms, mainly Nitszchia sp., were present in only moderate numbers $\left(1\right.$ to $3 \times 10^{6}$ cells $1^{-1}$ ) due to the low silicate concentrations, which were just above the detection limit $(1 \mu \mathrm{M})$

The sedimentation of algae in the first week coincided with a DMS peak that was very similar in all systems (Fig. 2). The DMS water $_{\text {concentration peak value }}$ was about $300 \mathrm{nM}$ at Days 4 and 5. The DMS $_{\text {water }}$ concentration was up to $50 \%$ of the amount of DMSP that could be detected during the first $7 \mathrm{~d}$ of the experiment. Whether DMS during this period originated from algal or bacterial DMSPlyase activity remains unclear. When both the efflux of DMS to the atmosphere and the bacterial consumption are taken into account, it seems likely that during this first DMSP peak most of the DMSP present in the water column was converted to DMS. The high DMS concentrations may be an effect of the density of the bloom induced, which practically consisted of a monoculture of the algae Phaeocystis sp. These high concentrations may also occur occasionally in the field during dense Phaeocystis sp. blooms in the Southern Ocean and North Sea (Crocker et al. 1995, S. Turner 
Fig. 3. DMSP concentrations and the $\mathrm{DMSP}_{\mathrm{p}} /$ chl a ratio for the 4 mesocosms. (A), (C) and (E): mesocosms 1 and 2 with sediment traps; (B). (D) and $(F)$ : mesocosms 3 and 4 without sediment traps. (A) and (B): particulate DMSP concentration: (C) and (D): dissolved DMSP concentration; (E) and (F): DMSP $_{p} /$ chl a ratio. Points show measurements and lines show averages between duplicate mesocosms
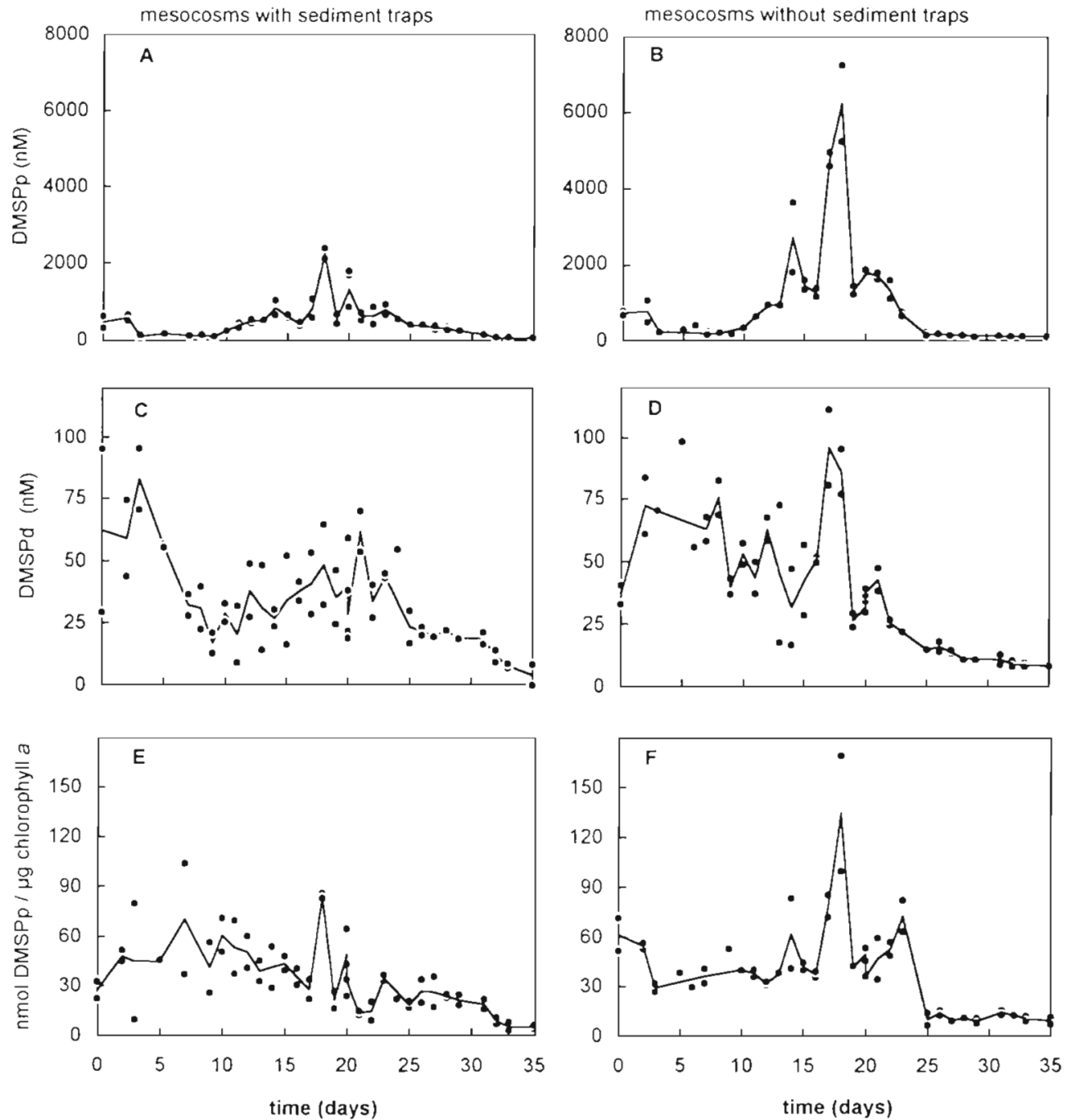

pers. comm.). From about Day 8 the DMS water concentration reached its base level again (about $4 \mathrm{nM}$ ). In mesocosms 3 and 4 (without sediment traps), the DMS $S_{\text {water }}$ concentration started to rise at Day 14 , reaching a value of approximately $400 \mathrm{nM}$ at the same day of the maximal chl a concentration (Day 17), after which

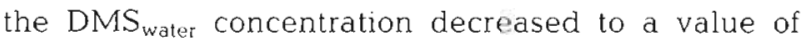
about 4 nM DMS at Day 24. The mesocosms with sediment traps (1 and 2) showed a much more rapid rise (Day 18 and 19) and fall (Days 20 to 23) in the concentration of $\mathrm{DMS}_{\text {water. The chl a peak was reached }}$ at Day 22. This substantial difference between mesocosms with and without traps remains to be explained. It is discussed in more detail in Osinga et al. 1996. Towards the end of the experiment the DMS concentration remained at a value of about $4 \mathrm{nM}$. From Fig. 2 it is evident that the second release of DMS started well before the Phaeocystis sp. bloom reached its maximum. This is consistent with our results ob- tained from the natural environment (Kwint \& Kramer 1996) and the results of Stefels \& Van Boekel (1993) who found the highest DMSP-lyase activity for exponentially growing cells of Phaeocystis sp. It is, however, in contrast to our findings reported before, for earlier mesocosm experiments carried out in spring and in autumn (Kwint \& Kramer 1995). This apparent discrepancy will be discussed below.

Towards the climax of the bloom, the DMSP con- $_{\mathrm{p}}$ centration rose sharply to a value of about $2500 \mathrm{nM}$ in mesocosms 1 and 2 (with sediment traps) and even up to $6500 \mathrm{nM}$ in mesocosms 3 and 4 (without sediment traps) (Fig. 3A, B). This concentration was 20-fold higher than the DMS $S_{\text {water }}$ concentration. The DMSP concentrations found in this experiment were extremely high compared to what is usually found in the field. Kwint \& Kramer (1996) reported maximum concentrations of DMSP of about $1500 \mathrm{nM}$. Chl a concentrations were not unusually high, however (a maxi- 
mum of about $60 \mu \mathrm{gl}^{-1}$ in the mesocosms compared to $65 \mathrm{\mu g} \mathrm{l}^{-1}$ during the field monitoring). The plankton bloom in this experiment consisted of an almost monoculture of Phaeocystis sp., which was not the case in the field.

The DMSP $/ \mathrm{chl}$ a ratio varied around a value of 50 to $60 \mathrm{nmol}$ DMSP $\mu \mathrm{g} \mathrm{chl} a^{-1}$ (Fig. 3E, F), with its highest values coinciding with the $\mathrm{DMS}_{\text {water }}$ maxima. In general the amount of DMSP $_{p}$ reflected the number of Phaeocystis sp. cells (Fig. 2). A maximum DMSP $/$ chl a occurred at around Day 18, just before the end of the phytoplankton bloom, which agrees well with the results of Matrai \& Keller (1993) who described a maximum DMSP content and release of DMS at the maximum of a bloom of Emiliania huxleyi in the Gulf of Maine.

Towards the end of our experiment where Phaeocystis sp. became less important, the $\mathrm{DMSP}_{\mathrm{p}} / \mathrm{chl}$ a ratio decreased to about $10 \mathrm{nmol} \mu^{-1}$. These ratios are comparable to the DMSP/chl a ratios found under natural conditions in this area. During a Phaeocystis sp. bloom in the Marsdiep (The Netherlands) tidal inlet, Kwint \& Kramer (1996) found a ratio of approximately $20 \mathrm{nmol}$ DMSP $\mu \mathrm{g} \mathrm{chl} a^{-1}$ that decreased to $12 \mathrm{nmol}$ DMSP $\mu \mathrm{g} \mathrm{chl} a^{-1}$ after the bloom had declined. We observed the general trend that a decrease in the DMSP $_{p}$ concentration coincides with an increase in the $\mathrm{DMS}_{\text {water }}$ concentration, although this is true only in a

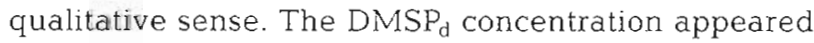
to be highly variable during the entire experiment, although there was a trend of a decrease from $100 \mathrm{nM}$ DMSP $_{d}$ at the start of the experiment to about $10 \mathrm{nM}$ DMSP $_{d}$ at the end, with some elevation during the DMS $_{\text {water }}$ peaks (Fig. 3C, D).

Interestingly, the increase in the DMS water $_{\text {concentra- }}$ tion following the decrease in $\mathrm{DMSP}_{\mathrm{p}}$ over the first $5 \mathrm{~d}$

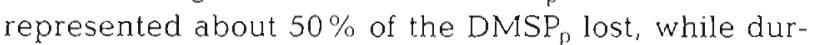
ing the decline of the major bloom (Days 18 to 25) DMS accumulation accounted for only $5 \%$ of the DMSP post. $_{\text {p }}$ The differences in the 2 periods cannot be accounted for by accumulation of $\mathrm{DMSP}_{d}$ (Fig. $3 \mathrm{C}, \mathrm{D}$ ). This indicates either that in the first period a lesser turnover of DMS orcurred, or that during the second bloom demethylation had a larger contribution to the degradation of DMSP than cleavage.

Maximum numbers of the copepod Temora longjcornis occurred before the maximum of chl $a$, and corresponded with the onset of maximum DMS release into the water column (Fig. 4). Differences between mesocosms with and without sediment traps did occur. Mesocosms without sediment traps (Fig. 4B) had lower copepod numbers (ca 100 vs $150 \mu^{-1}$ ) and high numbers of rotifers and rotifer eggs were found in the first $2 \mathrm{wk}$ of the experiment. The zooplankton may have stimulated $D M S P_{d}$ formation by feeding on the algal
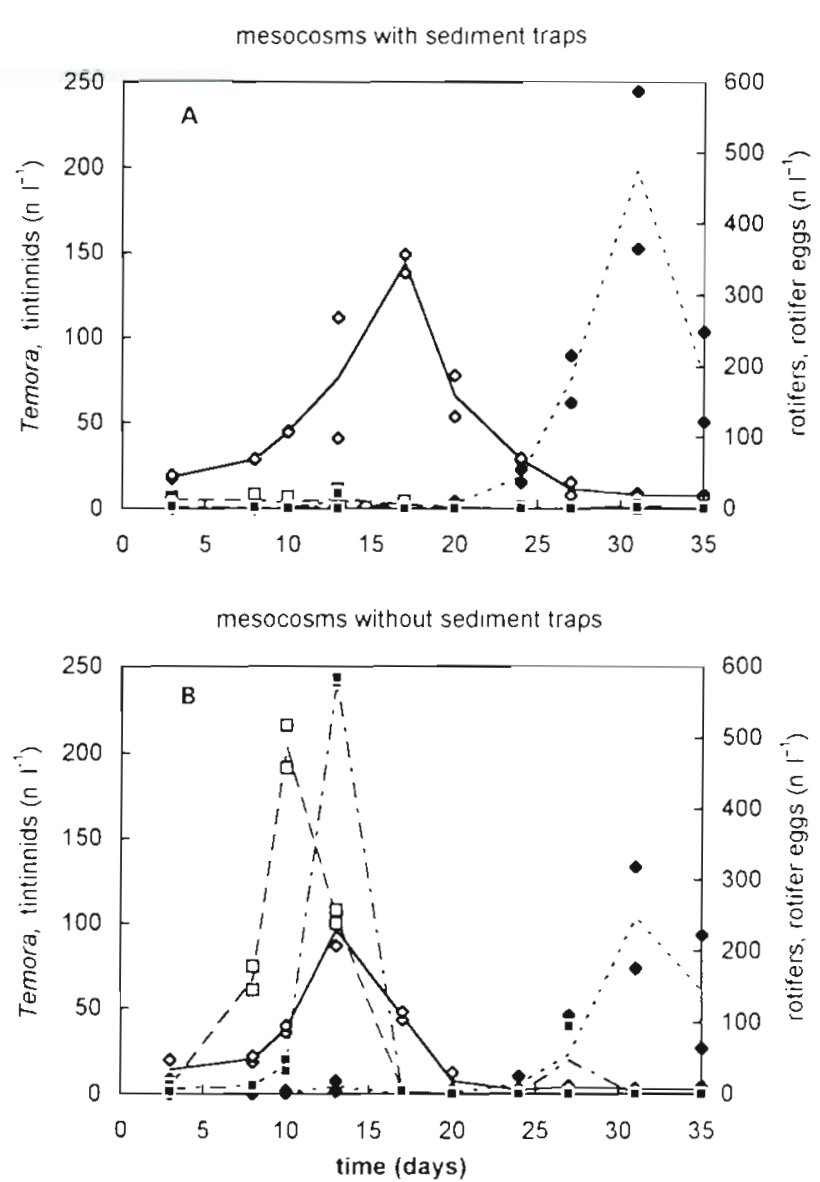

Fig. 4. Zooplankton numbers during the algal bloom: ( 0 ) Temora longicornis, $(\bullet)$ tintinnids, (ㅁ) rotifer eggs and ( $)$ rotifers. (A) mesocosms 1 and 2 with sediment traps; (B) mesocosms 3 and 4 without sediment traps. Points show measurements and lines show averages between duplicate mesocosms. Note different scales

cells (Dacey \& Wakeham 1986, Belviso et al. 1990, 1993, Hansen \& Van Boekel 1991, Hansen et al. 1994). However, the maxima of the zooplankton densities appear to have no direct relation to the accumulation of DMSP $P_{\jmath}$ and DMS $_{\text {water }}$.

Our experiment shows that in the mesocosms used, replicable results can be obtained concerning the course of the algal bloom, the production of DMSP and the release of DMS into the water column. The differences in the results between mesocosms with and without sediment traps may be explained by different resuspension of sedimented material. Due to the rigid sediment traps, the water column in those mesocosms with traps may have been less well mixed than in those without. The result was that less material was mineralized in the water column, explaining a less pronounced phytoplankton bloom, as well as the difference in zooplankton composition and sequence. 
Mesocosms are thus useful for studying the mechanisms controlling the turnover of DMSP and DMS. However, in mesocosm experiments the timescale of a phytoplankton bloom is compressed in time 2 to 3 times (Kuiper 1977). As the zooplankton bloom is restricted by the development of their different larval stages, the interrelations of phyto- and zooplankton can be seriously affected.

The total bacterial population density peaked twice during the mesocosm experiment. possibly due to the increase of particulate and dissolved organic matter originating from senescent algae (Fig. 5). The bacterial population had a base level of $2 \times 10^{9}$ cells $\mathrm{l}^{-1}$ and peaks of $8 \times 10^{9}$ and $6 \times 10^{9}$ cells $1^{-1}$ at Days 16 and 26 , respectively. The relatively moderate increase in bacterial numbers between base level and peaks (only 4 -fold) was already pointed out by several authors for a broad range of pelagic environments (as reviewed by Thingstad 1987). They proposed a mechanism where a strict regulation of bacterial densities would occur caused by viruses or predators such as nanoflagellates in pelagic systems

The DMS-utilizing bacteria, as determined by MPN method, constituted only a small fraction of the total bacterial population density (note the difference in scales in Fig. 5). The DMS-utilizing bacterial population started to grow shortly after the DMS water maximum. It peaked only after the second DMS peak with a maximal density of $5 \times 10^{6}$ cells $1^{-1}$ at Day 26 . From laboratory studies (data not shown) we know that there is a long lag-phase for bacteria to switch to DMS utilisation. The delay in response can also be explained by the low growth rate of most marine heterotrophic strains (Thingstad 1987). The observation that there are only few DMS-utilizing bacteria during the first $5 \mathrm{~d}$ of the experiment may account for the relatively high $\mathrm{DMS}_{\text {water }}$ concentration in relation to the available DMSP

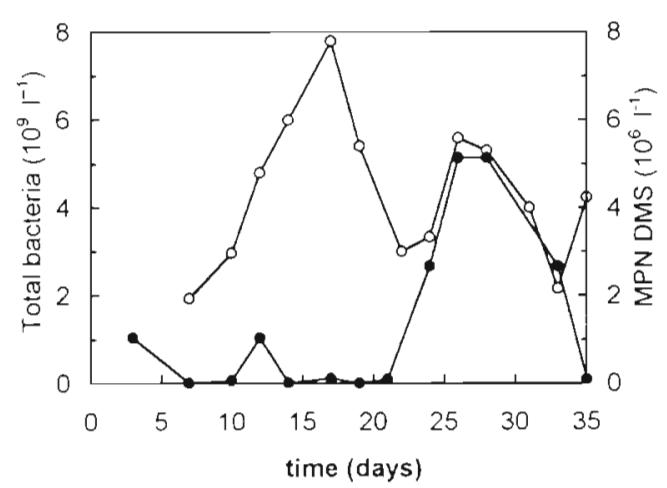

Fig. 5. Average bacterial numbers measured during the experment in mesocosms 1 and 3. Total bacteria (O) and most probable number of DMS-utilizing bacteria (MPN DMS; Note different scales

\section{DMSP cleavage versus demethylation}

In order to elucidate the role of DMSP-utilizing bacteria, subsamples collected from the mesocosms on 4 different days were incubated in the laboratory. The variables are summarized in Table 1 . In addition to the DMSP $_{\mathrm{p}}$ and DMSP concentrations, the estimated DMSP conversion rates are presented. The turnover rates $(V)$ are subdivided into turnover by cleavage and demethylation. Finally, the turnover time $(\tau$, in d) was given by the ratio of concentration to turnover rate. A high number thus indicates a slow turnover.

It appears that at Day $\overline{7}$, where a rather low concentration of DMSP is available (and possibly also a low number of DMSP-utilizing bacteria), the process of demethylation was the most important.

It was assumed that no increase in DMSP $_{p}$ would occur in the dark during the incubation experiments. This assumption was found to be not completely true, however. In some experiments an increase was detected. Quantification was not possible as the increase was the net result of production and consumption. The increase in $\mathrm{DMSP}_{\mathrm{p}}$ may be due to intracellular accumulation of DMSP $_{d}$ by bacteria (Ledyard \& Dacey 1994), or to the actual production of $\mathrm{DMSP}_{\mathrm{p}}$ by algae in the dark ( $\mathrm{J}$ Stefels pers. comm.). As a result, the net decrease in $\mathrm{DMSP}_{\mathrm{d}}$ can be underestimated. The turnover of $\mathrm{DMSP}_{\mathrm{d}}$ by demethylation was calculated by subtracting the net increase in DMS from the net DMSP $_{d}$ decrease, leading to an underestimation of the importance of demethylation, also because some DMS may have been consumed during the incubation. Due to the large headspace in the incubations, up to $28 \%$ of the DMS formed during the incubation may have been lost on sampling a bottle. As a different bottle was used for each point on the incubation curves, the results were not influenced in a relative sense.

Table 1. DMSP concentrations ([DMSP $\left.P_{p}\right]$ and $\left[\mathrm{DMSP}_{\mathrm{d}}\right]$ ), DMSP conversion rates $\left(\triangle D M S P_{p}\right.$ and $\left.\triangle D M S P_{d}\right)$, turnover rates by cleavage ( $\left.V_{\text {cleavage }}\right)$ and demethylation ( $\left.V_{\text {demethylaton }}\right)$, turnover time by cleavage $\left(\tau_{C l)}\right)$ and demethylation $\left(\tau_{D m}\right)$ and the ratio

$$
\tau_{C} / \tau_{D m}
$$

\begin{tabular}{|lcccc|}
\hline Parameter & Unit & \multicolumn{3}{c}{ Day } \\
& & 7 & 24 & 31 \\
\hline$\left[\mathrm{DMSP}_{\mathrm{p}}\right]$ & $\mathrm{nM}$ & 5.2 & 501.8 & 167.1 \\
{$\left[\mathrm{DMSP}_{\mathrm{d}} \mid\right.$} & $\mathrm{nM}$ & 25.9 & 54.9 & 21.4 \\
$\Delta \mathrm{DMSP}_{\mathrm{p}}$ & $\mathrm{nM} \mathrm{d}^{-1}$ & 39.0 & -795.0 & 682.0 \\
$\Delta \mathrm{DMSP}_{\mathrm{d}}$ & $\mathrm{nM} \mathrm{d}^{-1}$ & -35.0 & -1529.0 & 29.0 \\
$V_{\text {cleavage }}$ & $\mathrm{nM} \mathrm{d}^{-1}$ & 0.0 & 21.0 & 47.0 \\
$V_{\text {dxemethylation }}$ & $\mathrm{nM} \mathrm{d}^{-1}$ & 35.0 & 1508.0 & 0 \\
$\tau_{\mathrm{Cl}}$ & $\mathrm{d}$ & $\infty$ & 2.6 & 0.5 \\
$\tau_{\mathrm{Dm}}$ & $\mathrm{d}$ & 0.8 & 0 & $\infty$ \\
$\tau_{\mathrm{Cl}} / \tau_{\mathrm{Dm}}$ & - & $\infty$ & 70.0 & 0 \\
\hline
\end{tabular}


The DMSP-degrading population consisted of a variety of bacteria, using either of the 2 routes shown in Fig. 1. The inoculation of DMSP agarose plates with subsampled seawater from the mesocosms resulted in a broad spectrum of morphologically different, colony types. Some of them (less than $5 \%$ ) were agarolytic, but most of them were found to be positive for DMSP utilization. Fourteen different strains were nonrandomly selected (based on colony types) and characterized. Of these strains, 6 were capable of DMSP cleavage (P. Quist unpubl.).

\section{Turnover of DMS}

A comparison was made between the (calculated) flux of DMS to the atmosphere and the degradation of DMS by bacteria (Table 2). The flux was calculated from temperature, windspeed and the DMS water concentration. The bacterial production and consumption followed from the incubation experiments for the $4 \mathrm{~d}$ of measurements. As before, $\tau$ represents the turnover time, $\tau_{b_{10}}$ for biological consumption and $\tau_{a t m}$ for atmospheric flux. When the ratio $\tau_{a t m} / \tau_{\text {bio }}$ is larger than 1, it reflects the dominance of bacterial degradation over flux to the atmosphere as a sink for DMS. It appears that for all $4 \mathrm{~d}$ for which there was data, the bacterial breakdown is by far the most important process, usually by a factor of 10 or more. Only at the end of the mesocosm experiment (Day 31), did both processes become comparable. The bacterial breakdown was still, by a factor of 3 , more important than the flux to the atmosphere. In field experiments, Kiene \& Bates (1990) found a similar $10 \%$ atmospheric flux for a system with a low $\mathrm{DMS}_{\text {water }}$ concentration (1 to $10 \mathrm{nM}$ ) Our results may be influenced by the fact that chloroform did not always totally inhibit the biological DMS consumption. In samples with a high algal biomass content, the chloroform appeared to be less effective than in samples with low algal biomass, so these data were not used. The exact cause for this is not yet clear. After the completion of these mesocosm experiments, Visscher \& Taylor (1993) reported a new mechanism for the bacterial breakdown of DMS which was not sensitive to inhibition by chlo- roform. Wolfe \& Kiene (1993) showed that in some cases chloroform may cause a release of DMSP and stimulate DMS production leading to an overestimation of the DMS consumption by a factor of about 2 . In our experiments, the estimated bacterial DMS consumption was a factor 10 or more important than the flux to the atmosphere, so we can still conclude that bacterial degradation, rather than atmospheric flux, is a main sink for DMS

Because of the direct relation between the flux and the $\mathrm{DMS}_{\text {water }}$ concentration in our experiment, the seaair exchange of DMS may be heavily affected by the short periods of high $\mathrm{DMS}_{\text {water }}$ concentration. To expand our findings to periods of high DMS concentration, the daily fluxes to the atmosphere were calculated for the entire period of the experiment. In Fig 6 the flux of DMS is compared to the total amount of DMS present in the mesocosm. A decrease in the total amount of DMS is the result of flux to the atmosphere and bacterial degradation and/or photooxidation. It is not possible to comment on the importance of the

Table 2. Temperature, windspeed, DMS concentrations, rates of bacterial production and consumption, biological turnover time $\left(\tau_{\text {bio }}\right)$, turnover time by efflux of DMS $\left(\tau_{a t m}\right)$ and the ratio $\tau_{a t m} / \tau_{\text {bio }}$

\begin{tabular}{|c|c|c|c|c|c|}
\hline \multirow{2}{*}{ Parameter } & \multirow[t]{2}{*}{ Unit } & \multicolumn{4}{|c|}{ Day } \\
\hline & & 7 & 10 & 24 & 31 \\
\hline Temperature & ${ }^{\circ} \mathrm{C}$ & 10.2 & 12.2 & 13.6 & 13.6 \\
\hline Windspeed & m. $\mathrm{s}^{-1}$ & 5.0 & 4.5 & 4.5 & 7.0 \\
\hline [DMS] & $\mathrm{nM}$ & 64.7 & 6.0 & 13.4 & 8.0 \\
\hline Bactenal production & $n M d^{-1}$ & 0 & 26.0 & 21.0 & 47.0 \\
\hline Bactenal consumption & $n M d^{-1}$ & 178.0 & 26.0 & 28.0 & 14.0 \\
\hline$t_{\text {bio }}$ & $\mathrm{d}$ & 0.4 & 0.2 & 0.5 & 0.6 \\
\hline Flux & $\mu \mathrm{mol} \mathrm{m}^{-2} \mathrm{~d}^{-1}$ & 61.1 & 4.3 & 9.4 & 15.5 \\
\hline$\tau_{\text {atm }}$ & $\mathrm{d}$ & 3.6 & 4.8 & 4.9 & 1.8 \\
\hline$\tau_{\text {atmm }} / \tau_{\text {bюо }}$ & - & 10.1 & 21.0 & 10.0 & 3.1 \\
\hline
\end{tabular}

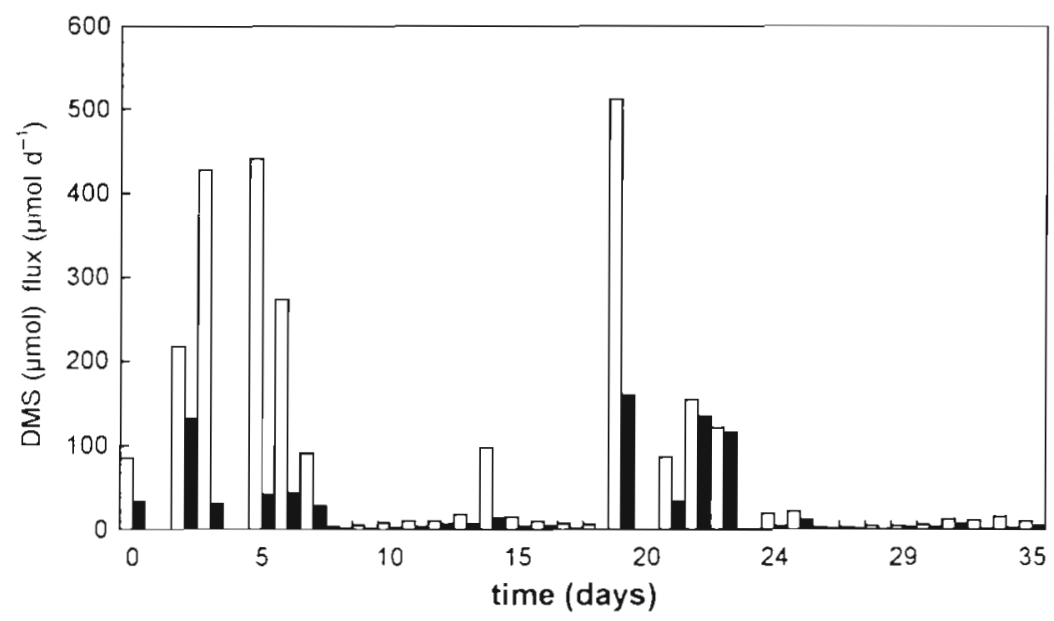

Fig. 6. Calculated total flux of DMS (black bars) from mesocosm 1 and the total amount of DMS (open bars) present in mesocosm 1 
atmospheric flux in periods with a high production of DMS, as the DMS water concentration is the net result of production and degradation/efflux. However, in situations where a strong decrease in the DMS concentration is observed, the calculated flux can only be responsible to a minor extent for the decrease in DMS $_{\text {water. }}$ During Days 5 to 8 the flux to the atmosphere was very small compared to the amount of DMS that disappeared from the mesocosm. For Days 19 to 24 the flux to the atmosphere appeared to be more important, but the bacterial consumption still remains the dominant sink for DMS (compare Day 24 in Table 2 and Fig. 6).

In order to investigate whether the bacterial conversion rates are realistic, a comparison was made with data obtained from cultures of bacterial strains as documented in the literature. In continuous culture experiments, a specific conversion rate of $100 \mu \mathrm{mol}$ DMS mg protein ${ }^{-1} \mathrm{~d}^{-1}$ was found for Thiobacillus thioparus (Visscher et al. 1991)

From a bacterial strain isolated from the epidermal surface of Ulva lactuca, conversion rates in the order of 36 and $27 \mu \mathrm{mol}$ DMS mg protein ${ }^{-1} \mathrm{~d}^{-1}$ were measured in continuous culture growth experiments and by monitoring the oxygen consumption in batch cultures, respectively ( $\mathrm{P}$. Quist unpubl.). In our experiments described here, a specific conversion rate on the order of 10 to $1000 \mu \mathrm{mol}$ DMS mg protein ${ }^{-1} \mathrm{~d}^{-1}$ was found by combining the population density of $5 \times 10^{6}$ cells $^{-1}$ with the bacterial turnover of DMS (assuming $20 \mathrm{fg}$ protein per cell). As MPNs are most likely an underestimation of the true DMS-utilizing population (due to the selectivity of the medium), the specific uptake rates may be lower under field conditions.

\section{Conclusion}

Our data show that DMS release or production is not necessarily associated with the senescent phase of a phytoplankton bloom as found by Kwint \& Kramer (1995). The first $D M S_{\text {water }}$ peak coincided with the senescent phase of the algae, while the second DMS peak corresponded to a maximum in Phaeocystis sp. cells per litre. Most probably the first DMS peak was an artefact of the experiment caused by the settlement and degradation of algae. During this period $\mathrm{DMSP}_{\mathrm{d}}$ became quickly available and its degradation led to a build up of DMS.

Data on the flux of DMS to the atmosphere, bacterial DMS consumption rates and DMSP turnover show that bacterial consumption is the main sink for DMS even under conditions of high DMS water $_{\text {concentrations pre- }}$ sent during an algal bloom. We found that during a phytoplankton bloom an increasing part of the DMSP produced is not metabolized to DMS at all, but that the alternative pathway involving DMSP demethylation (Fig. 1) is more important. During the initial phase of a phytoplankton bloom, DMSP may be converted to DMS with high efficiency

Our results suggest that DMS and DMSP are rapidly cycled in the water column due to bacterial activity and that the flux of DMS to the atmosphere is highly dependent on factors other than the production of cellular DMSP by phytoplankton alone.

Acknowledgements. This study was financially supported by the Netherlands Ministry of Housing, Physıcal Planning and the Environment National Research Program (project NOLK 026/90j. We thank Jacqueline Stefels for testing the effect of chloroform on the DMSP-lyase activity of Phaeocystis sp. and Siem Hoorsman, Marijke van der Meer and Irma van der Veen for their technical assistance.

\section{LITERATURE CITED}

Andreae MO (1990) Ocean-atmosphere interactions in the global biogeochemical sulfur cycle. Mar Chem 30:1-29

Ayers GP, Gras JL (1991) Seasonal relationship between cloud condensatıng nuclei and aerosol methanesulphonate in marine air. Nature 353:744-747

Bates TS, Charlson RJ, Gammon RH (1987) Evidence for the climatic role of marine biogenic sulphur. Nature 329 : 319-321

Belviso S, Buat-Menard P, Nguyen BC, Claustre H, Neveux J (1993) Size distribution of dimethylsulfoniopropionate (DMSP) in areas of the tropical northeastern Atlantic Ocean and the Mediterranean Sea. Mar Chem 44:55-71

Belviso S, Kim SK, Rassoulzadegan F, Krajka B, Nguyen BC, Mihalopoulos N, Buat-Menard P (1990) Production of dimethylsulfonıum propionate (DMSP) and dimethylsulfide (DMS) by a microbial food web. Limnol Oceanogr 35: $1810-1821$

Brimblecombe P, Shooter D (1986) Photo-oxidation of dimethylsulphide in aqueous solution. Mar Chem 19:343-353

Chambers ST, Kunin CM, Miller D, Hamada A (1987) Dimethylthetin can substitute for glycine betaine as an osmoprotectant molecule for Escherichia coli. J Bacteriol 169:4845-4847

Charlson RJ, Langner J, Rodhe H, Leovy CB, Warren SG (1991) Perturbation of the northern hemisphere radiative balance by backscattering from anthropogenic sulfate derosols. Tellus 43:152-163

Charlson RJ, Lovelock JE, Andreae MO, Warren SG (1987) Oceanic phytoplankton, atmospheric sulphur, cloud albedo and climate. Nature 326:655-661

Crocker KM, Ondrusek ME, Petty RL, Smith RC (1995) Dimethylsulfide, algal pigments and light in an Antarctic Phaeocystis sp. bloom. Mar Biol 124:335-340

Dacey JWH, Blough N (1987) Hydroxide decomposition of DMSP to form DMS. Geophys Res Lett 14:1246-1249

Dacey JWH, Wakeham SG (1986) Oceanic dimethylsulfıde: production during zooplankton grazıng on phytoplankton. Science 233:1314-1316

De Man JC (1975) The probability of most probable numbers. Eur J Appl Microbiol Biotechnol 1:67-78

De Souza MP, Yoch DC (1995) Purification and characterisation of dimethylsulfoniopropionate-lyase from an Alcali- 
genes-like dimethyl sulfide-producing marine isolate. Appl Environ Microbiol 61:21-26

Dickson DMJ, Kirst GO (1987a) Osmotıc adjustment in marine eukaryotic algae: the role of inorganic ions, quaternary ammonum, tertiary sulphonium and carbohydrate solutes 1. Diatoms and a Rhodophyte. New Phytol 106:645-656

Dickson DMJ, Kırst GO (1987b) Osmotic adjustment in marne eukaryotic algae: the role of inorganic ions, quaternary ammonium, tertiary sulphonium and carbohydrate solutes. II. Prasinophytes and Haptophytes. New Phytol 106:657-666

Hansen B, Verity P, Falkenhaug T, Tande KS, Norrbin F (1994) On the trophic fate of Phaeocystis pouchettii (Harrot). V. Trophic relationships between Phaeocystis and zooplankton: an assessment of methods and size dependence. J Plankton Res 16:487-511

Hansen FC, Van Boekel WHM (1991) Grazing pressure of the calanoid copepod Temora longicornis on a Phaeocystis dominated spring bloom in a Dutch tidal inlet. Mar Ecol Prog Ser 78:123-129

Hobbie JE, Daley RJ, Jasper S (1977) Use of nucleopore filters for counting bacteria by fluorescence microscopy. Appl Environ Microbiol 33:1225-1228

Janvier M, Frehel C, Grimont F, Gasser F (1985) Methylophaga marina gen. nov. and Methylophaga thalassica sp. nov., marine methylotrophs. Int J Syst Bacterol 35: $1.31-139$

Keller MD, Bellows WK, Guillard RRL (1989) Dimethyl sulfide production in marine phytoplankton. In: Saltzman ES, Cooper WJ (eds) Biogenic sulfur in the environment. ACS Symp Ser 393, American Chemical Society, Washington, DC, p 167-182

Kiene RP (1992) Dynamics of dimethyl sulfide and dimethy]sulfoniopropionate in oceanic water samples. Mar Chem 37:29-52

Kiene RP, Bates TS (1990) Biological removal of dimethyl sulfide from sea water. Nature 345:702-705

Klee AJ (1993) A computer program for the determination of most probable number and its confidence limits. J Microbiol Methods 18:91-98

Kuiper J (1977) Development of North Sea coastal plankton communitıes in separate plastic bags under identical conditions. Mar Biol 44:97-107

Kuiper J (1981) Fate and effects of cadmium in marine plankton communities in experimental enclosures. Mar Ecol Prog Ser 6:161-174

Kwint RLJ, Kramer KJM (1995) DMS production by plankton communities. Mar Ecol Prog Ser 121:227-237

Kwint RLJ, Kramer KJM (1996) The annual cycle of the production and fate of DMS and DMSP in a marine coastal system. Mar Ecol Prog Ser 134:217-224

Leck C, Larsson U, Bàgander LE, Johansson S, Hajdu S (1990) Dimethyl sulfide in the Baltic Sca: annual variability in relation to biological activity. J Geophys Res 95(C3): $3353-3363$

Ledyard KM, Dacey JWH (1994) Dimethylsulfide production from dimethylsulfoniopropionate by a marine bacterium. Mar Ecol Prog Ser 110:95-103

Lindqvist F (1989) Sulphur-specific detection in air by photoionization in a multiple detector gas chromatography system. J High Resolut Chromatogr 12:628-631

Liss PS, Malin G, Holligan PM (1994) Dimethyl sulphide and

This article was submitted to the editor
Phaeocystis: a review. J Mar Syst 5:41-53

Liss PS, Merlivat L (1986) Air-sea gas exchange rates: introduction and synthesis. In: Buart-Menard $P(e d)$ The role of air-sea exchange in geochemical cycling. Reidel, Dordrecht, p 113-127

Lovelock JE, Maggs RJ, Rasmussen RA (1972) Atmospheric dimethyl sulphude and the natural sulphur cycle. Nature $237: 452-453$

Malin G, Turner S, Liss P, Holligan P, Harbour D (1993) Dimethylsulphide and dimethvisulfoniopropionate in the northeast Atlantic during the summer coccolithophore bloom. Deep Sea Res Part I Oceanogr Res Pap 40(7): $1487-1508$

Matrai PA, Keller MD (1993) Dimethylsulfıde in a large scale coccolithophore bloom in the Gulf of Maine. Cont Shelf Res 13:831-843

Matrai PA, Keller MD (1994) Total organic sulfur and dimethylsulfoniopropionate in marine phytoplankton: intracellular variations. Mar Biol 119:61-68

Matrai PA, Vernet $M$, Hood R, Jennings A, Brody E, Saemundsdóttir S (1995) Light-dependence of carbon and sulfur production by polar clones of the genus Phaeocystis. Mar Biol 124:157-167

Nguyen BC, Belviso S, Mihalopoulos N, Gostan J, Nival P (1988) Dimethyl sulfide production during natural phytoplanktonic blooms. Mar Chem 24:133-141

Osinga R, Kwint RLJ, Lewis WE, Kraay (iW, Lont JD, Lindeboom HJ, Van Duyl FC (1996) Production and fate of dimethylsulfide and dimethylsulfoniopropionate in pelagic mesocosms. The role of sedimentation. Mar Ecol Prog Ser 131:275-286

Parsons RT, Maita Y, Lalli CM (1984) A manual of chemical and biological methods for seawater analysıs. Pergamon Press, Oxford, p 3-111

Stefels J, Dijkhuizen L, Gieskes WWC (1995) DMSP-lyase activity in a spring phytoplankton bloom off the Dutch coast, related to Phaeocystis sp. abundance. Mar Ecol Prog Ser 123:235-243

Stefels J, Van Boekel WHM (1993) Production of DMS from dissolved DMSP in axenic cultures of the marine phytoplankton species Phaeocystis sp. Mar Ecol Prog Ser 97 . $11-18$

Taylor BF. Gilchrist DC (1991) New routes for aerobic biodegradation of dimethylsulfoniopropionate. Appl Environ Microbiol 57:3581-3584

Thingstad TE (1987) Analyzing the microbial loop. PhD thesis, University of Bergen

Vairavamurthy A, Andreae MO, Iverson RL (1985) Biosynthesis of dimethyl sulfide and dimethylpropiothetin by Hymenomonas carterae in relation to sulfur source and salinity variations. Limnol Oceanogr 30:59-70

Visscher PT, Quist P, Van Gemerden H (1991) Methylated sulfur compounds in microbial mats: in sifu concentrations and metabolism by a colorless sulfur bacterium. Appl Environ Microbiol 57:1758-1763

Visscher PT, Taylor BF (1993) A new mechanism for the aerobic catabolism of dimethyl sulfide. Appl Environ Microbiol 59:3784-3789

Wolfe GV, Kiene RP (1993) Radioisotope and chemical inhibitor measurements of dimethyl sulfide consumption rates and kinetics in estuarine waters. Mar Ecol Prog Ser 99:261-269

Manuscript first received: August 9, 1995

Revised version accepted: September 24, 1996 